\title{
Vegetation composition and shrub extent on the Yukon coast, Canada, are strongly linked to ice-wedge polygon degradation
}

\author{
Juliane Wolter, ${ }^{1,2}$ Hugues Lantuit, ${ }^{1,2}$ Michael Fritz, ${ }^{1}$ Marc Macias-Fauria, ${ }^{3}$ \\ Isla Myers-Smith ${ }^{4}$ \& Ulrike Herzschuh ${ }^{1,2}$ \\ ${ }^{1}$ Alfred Wegener Institute Helmholtz Centre for Polar and Marine Research, Telegrafenberg A43, DE-14473, Potsdam, Germany \\ 2 Institute of Earth and Environmental Science, University of Potsdam, Karl-Liebknecht-Str. 24-25, DE-14476, Potsdam, Germany \\ ${ }^{3}$ School of Geography and the Environment, Oxford University Centre for the Environment, University of Oxford, South Parks Road, \\ Oxford OX1 3QY, UK \\ ${ }^{4}$ School of GeoSciences, University of Edinburgh, 113 Crew Building, The King's Buildings, Alexander Crum Brown Road, Edinburgh, EH9 3FF, UK
}

\section{Keywords}

Ice-wedge polygon mires; western

Canadian Arctic; modern vegetation;

microtopography; permafrost.

\section{Correspondence}

Juliane Wolter, Alfred Wegener

Institute Helmholtz Centre for Polar

and Marine Research, Telegrafenberg A43,

DE-14473 Potsdam, Germany.

E-mail: juliane.wolter@awi.de

\begin{abstract}
Changing environmental and geomorphological conditions are resulting in vegetation change in ice-wedge polygons in Arctic tundra. However, we do not yet know how microscale vegetation patterns relate to individual environmental and geomorphological parameters. This work aims at examining these relations in polygonal terrain. We analysed composition and cover of vascular plant taxa and surface height, active layer depth, soil temperature, carbon and nitrogen content, $\mathrm{pH}$ and electrical conductivity in four polygon mires located on the Yukon coast. We found that vascular plant species composition and cover correlates best with relative surface height. Ridges of low-centred polygons and raised centres of high-centred polygons support the growth of mesic and wetland species (e.g., Betula glandulosa, Salix pulchra, S. reticulata, Rubus chamaemorus, various ericaceous dwarf shrubs, Eriophorum vaginatum, Poa arctica). Wetland and aquatic plant species (e.g., E. angustifolium, Carex aquatilis, C. chordorrhiza, Pedicularis sudetica) grow in low-lying centres of polygons and in troughs between polygons. We also found a relationship between vascular plant species composition and substrate characteristics such as $\mathrm{pH}$, electrical conductivity and total organic carbon, although the individual influence of these parameters could not be determined because of their correlation with relative surface height. Our findings stress the regulatory role of microtopography and substrate in vegetation dynamics of polygonal terrain. Ongoing warming in this region will lead to changes to polygonal terrain through permafrost degradation and subsequent conversion of low-centred into highcentred polygons. Our results indicate that shrubs, particularly Betula glandulosa and heath species, have the potential to expand most.
\end{abstract}

To access the supplementary material for this article, please see the supplementary files under Article Tools, online.
The recent warming trend at high latitudes is leading to ecological, hydrological and permafrost changes in Arctic tundra ecosystems (Barros et al. 2014). Thawing permafrost and extended growing seasons will potentially affect vast expanses of Arctic wetlands and wetland vegetation, but the mechanisms involved and the direction of change are still unclear.

Ice-wedge polygon mires are a common wetland type of Arctic lowlands (French 2007). A low-centred polygon type develops in polygonal nets of ice wedges, where flat 


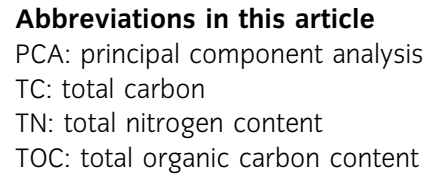

to slightly sloping permafrost ground provides a watersaturated and poorly drained surface (Washburn 1979). High-centred polygons are thought to develop from degrading low-centred polygons affected by melting ice wedges (Mackay 2000) and improved drainage conditions (French 2007). There are intermediate forms between these two general types.

Ice wedge degradation leading to a relief inversion in low-centred polygons has been observed over the past decades, and has in part been attributed to increasing mean ground temperatures (Jorgenson et al. 2006; Necsoiu et al. 2013). The reorganization of low-centred polygons into high-centred polygons is irreversible on decadal to centennial timescales: either a new stable state is reached (Jorgenson et al. 2006; Ellis et al. 2008) or the polygons are further degraded and eroded (Fortier et al. 2007). Such changes to surface topography may induce significant modifications to landscape hydrology and the depth of the active layer (the seasonally thawed top layer of the ground), and change growing conditions for plants (Ellis et al. 2008).

Changes in the vegetation cover can in turn alter the permafrost ground thermal regime substantially by modifying insulation, albedo and heat conduction (Walker et al. 2003). Mosses, graminoids and shrubs are the most dominant plant groups in polygon mires (Bliss 1956). In this study we focus on vascular plants and their relation with environmental parameters. Shrub taxa are especially important in the context of recent change and insulation of permafrost. Shrubs insulate the ground against extreme cold by trapping snow in winter, but they also provide shade in summer, reducing the amount of solar radiation reaching the ground (Myers-Smith, Forbes et al. 2011). Depending on growth form and canopy height, either of these effects may dominate, reducing or increasing active layer depths.

Recent studies show an overall increase in shrub abundance and biomass in the circum-Arctic tundra (Tape et al. 2006; Frost 8 Epstein 2014). On the regional to global level, shrub growth is limited by summer air temperatures and the length of the growing season (Myers-Smith, Forbes et al. 2011; Myers-Smith et al. 2015), while locally other factors such as topography, hydrology and nutrient availability can become limiting (Shaver \& Chapin 1980; Walker 2000; Naito \& Cairns 2011; Ropars \& Boudreau 2012), making the response of vegetation to climatic change more heterogeneous (Lantz et al. 2010; Frost et al. 2014).

The complex relationships between vegetation and polygon mire development have been studied locally in very few places in the circumpolar Arctic (Ellis et al. 2008; de Klerk et al. 2011; Zibulski et al. 2013; de Klerk et al. 2014; Fritz et al. 2016) and are still poorly understood. There is little information available on environmental constraints to shrub composition in polygon mires. This impedes our capacity to determine which species are likely to gain from changing environmental conditions in the vast polygonal lowlands of the Arctic.

In this study we investigate vascular plant species composition and abundance in four polygon mires on the Yukon Coastal Plain and Herschel Island along with physical environmental parameters to provide a baseline against which to assess past, present and future change in vegetation composition in polygon mires.

The objectives of this paper are: (1) to identify patterns in vascular plant species composition and cover and relate them to microtopography and substrate in ice-wedge polygon mires; and (2) to discuss the potential of icewedge polygon mires as sites of shrub expansion and the susceptibility of different ice-wedge polygon types to shrub expansion.

\section{Study area}

The Yukon Coastal Plain is part of a Low Arctic transition zone between low-shrub tundra and dwarf-shrub tundra, where the response of vegetation to warming is predicted to be fastest (Lantz et al. 2010; Myers-Smith et al. 2015). The study area lies within the region of continuous permafrost (Brown et al. 1997). Wetlands cover about $25-50 \%$ of its surface (Hagenstein et al. 1999). The coastal plain is a $10-40 \mathrm{~km}$ wide strip of flat to gently sloping terrain stretching over $200 \mathrm{~km}$ from the YukonAlaskan border to the Mackenzie Delta (Fig. 1). It is confined between the British Mountains to the south and the Beaufort Sea to the north. The Yukon Coastal Plain was partially glaciated during the Late Wisconsin (23-16 thousand years before AD 1950), when the Laurentide Ice Sheet extended into the study area west of Herschel Island (a push moraine) beyond the modern Firth River approximately to $139.6^{\circ} \mathrm{W}$ (Mackay 1959; Dyke \& Prest 1987; Fritz et al. 2012). The accumulated sediments are of Holocene and Pleistocene origin topped by a thin layer of peaty organic soil, which is thicker in the western, unglaciated part of the Yukon Coastal Plain (Rampton 1982). Ice-wedge growth and degradation, thermokarst and thermal erosion are the main geomorphic processes shaping the landscape. 


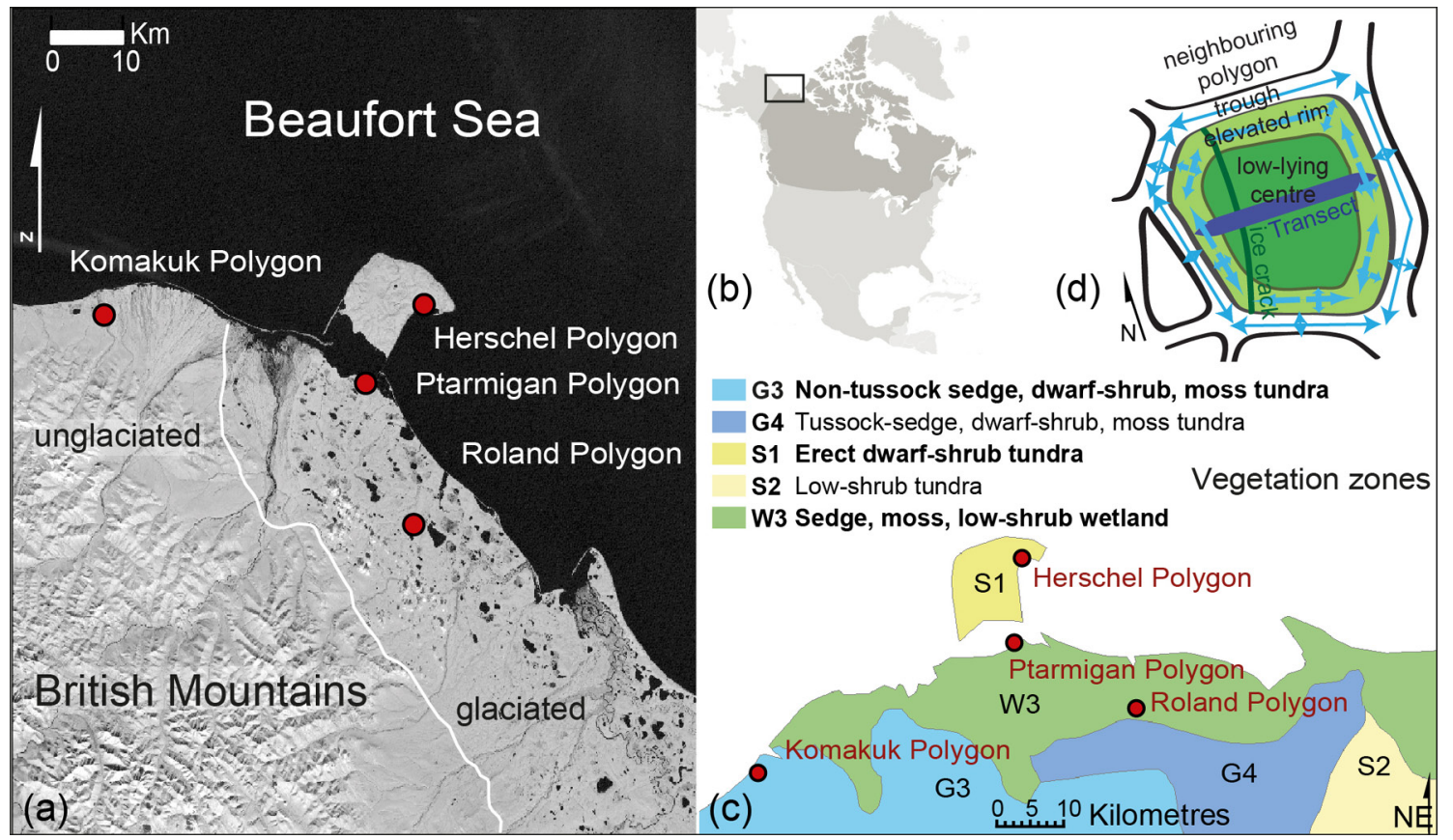

Fig. 1 Location of study area. (a) The studied ice-wedge polygon mires are situated on the Yukon Coastal Plain and Herschel Island within and beyond the reconstructed limit of Quaternary glaciation (white line). Map based on Landsat imagery. (b) Location of study area in North America. (c) Vegetation zones of the wider study region (modified from the Circumpolar Arctic Vegetation Map [CAVM 2013]). (d) Schematic drawing of ice-wedge polygon and measured polygon dimensions.

Mean annual air temperatures on the Yukon coast range between $-11.0^{\circ} \mathrm{C}$ (Komakuk Beach) and $-9.9^{\circ} \mathrm{C}$ (Shingle Point), whereas mean July air temperatures range from $7.8^{\circ} \mathrm{C}$ at Komakuk Beach to $11.2^{\circ} \mathrm{C}$ at Shingle Point (30-year means for 1971-2000 obtained from Environment Canada [www.climate.weather.gc.ca]). Both climate stations are situated on the coast, and summer temperatures are likely to be slightly higher a few kilometres inland. The influence of the cold sea on regional climate during summer shortens the growing season compared with locations further inland (Haugen \& Brown 1980; Burn 1997). Mean annual precipitation ranges from $161.3 \mathrm{~mm}$ (Komakuk Beach) to $253.9 \mathrm{~mm}$ (Shingle Point). The snow cover prevails for about 250 days per year and average snow depths are between 20 and $35 \mathrm{~cm}$. There is strong variation in snow depths, as snow is redistributed by wind on the treeless landscape (Burn \& Zhang 2009). Snow will generally accumulate in depressions and concave slopes, while exposed or elevated areas are virtually blown clear of snow.

The typical vegetation consists of sedges, mosses and erect dwarf shrubs ( $<40 \mathrm{~cm}$ tall) or low shrubs $(>40 \mathrm{~cm}$ ) (Walker et al. 2005). The Circumpolar Arctic vegetation map (CAVM Team 2003) classified the mainland part of our study area as sedge, moss, low-shrub tundra (Fig. 1c). Herschel Island is classified as erect dwarf-shrub tundra (Fig. 1c). In protected locations, especially in river valleys in the foothills of the British Mountains, conditions support the growth of shrubs taller than $40 \mathrm{~cm}$ and even trees (Picea mariana, Populus balsamifera).

\section{Methods}

\section{Fieldwork}

During July and August 2012 and July 2013, four polygon mires were investigated on the Yukon coast (Supplementary Fig. S1). The four polygon mires are located in four different landscape units on the Yukon Coastal Plain (Table 1). Each study site has its own substrate characteristics and hydrological conditions, while sharing regional climate and biome.

For all polygons, dimensions (i.e., diameter, length and width of the polygon ridges and troughs) were measured and their physical morphology was described (Fig. 1d). The method of surveying ice-wedge polygons in high spatial resolution was adapted from de Klerk et al. (2009) and Minke et al. (2009). Transects of $1 \times 1 \mathrm{~m}$ plots were laid through Herschel, Komakuk and Roland polygons (Fig. 2). Transects had lengths of 16, 10 and $8 \mathrm{~m}$, respectively, and reached across each polygon from rim to rim. The high-centred polygon (Roland Polygon) was measured 


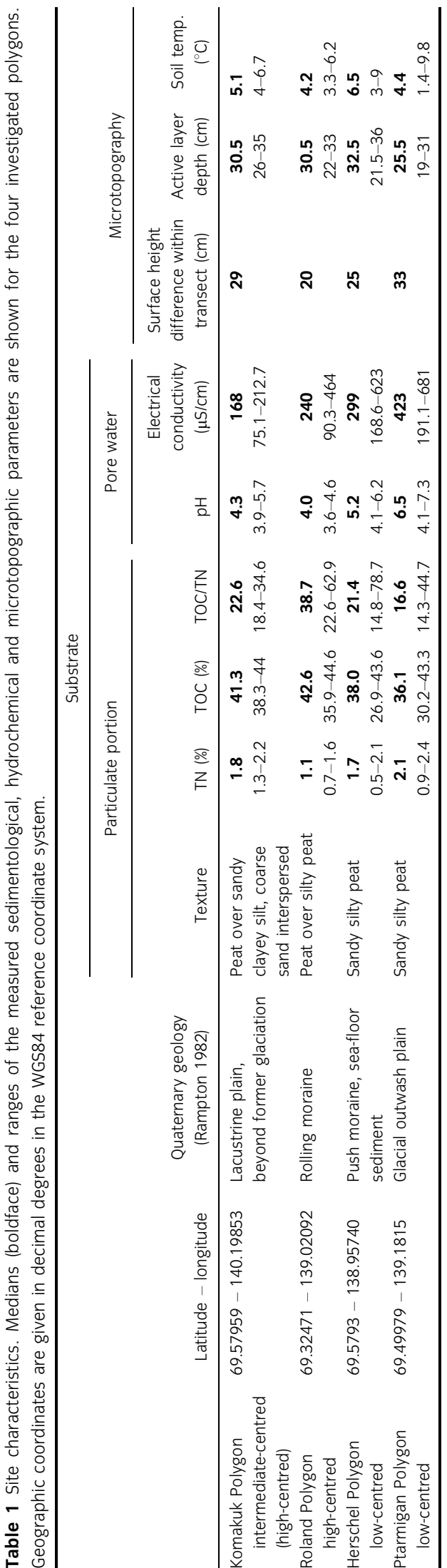

from trough to trough. In each plot, relative surface height, active layer depth and soil temperature were measured, a sediment surface sample was taken and the vegetation was recorded. Vegetation surveys of vascular plants followed a modified Braun-Blanquet approach (Braun-Blanquet 1964; Westhoff \& Van Der Maarel 1978) using exact cover percentages. Relative surface height and relative height of the permafrost table were measured relative to a reference surface provided by cords stretched across each polygon. The reference height for these two parameters was defined as the highest point in each transect. The water table was not visible within all polygons and could not be used as reference height. We gave the highest point the value zero; all other surface heights and permafrost table heights were therefore negative. Active layer depth was measured using a metal rod. Soil temperatures were measured at $10 \mathrm{~cm}$ depth below the surface using a soil thermometer.

In 2013, the low-centred Ptarmigan Polygon was surveyed in $1 \times 1 \mathrm{~m}$ grid cells across the polygon and beyond it into the adjoining troughs and neighbouring polygons, resulting in a grid of $25 \times 18 \mathrm{~m}$. Surveying followed the methods used in the previous year. Relative surface height, active layer depth and soil temperatures were measured in all grid cells. Surface samples were taken in each grid cell along one transect through the polygon. The vegetation was surveyed in two perpendicular transects using the same approach as in 2012.

\section{Laboratory and statistical analyses}

Laboratory analyses were performed at the Alfred Wegener Institute Helmholtz Centre for Polar and Marine Research in Potsdam, Germany. In order to describe the substrate, surface sediment samples were analysed for TC, TOC and TN. TOC, TC and TN contents are given in weight percent $(\mathrm{wt} \%)$. Pore water from all surface samples was analysed for electrical conductivity and $\mathrm{pH}$. Texture descriptions were made using peat monoliths from the active layer.

We used the statistics software R, version 3.0.2 (R Core Team 2013). PCA and environmental fitting were used to address our first goal of examining patterns in vascular plant species composition and cover and of finding links between environmental parameters and vegetation parameters. We used Hellinger-transformed percent cover data of 19 vascular plant taxa which occurred in at least five plots and in at least two of the polygons to minimize overrepresentation of rare taxa with low cover (ter Braak 1983; Rao 1995). PCA was performed using the function "rda" in the vegan package in R (Oksanen et al. 2013). 


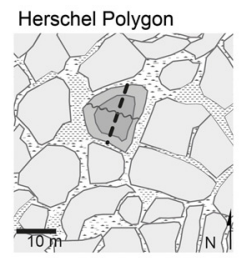

Low-centred
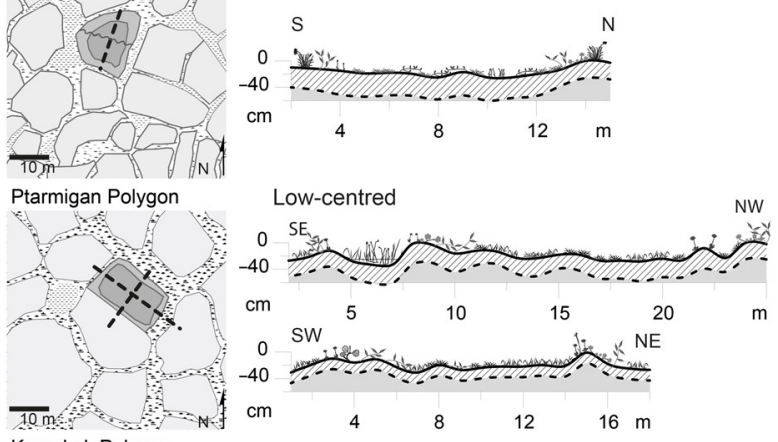

Komakuk Polygon

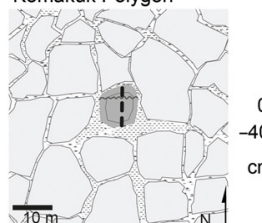

Intermediate-centred Transect profiles

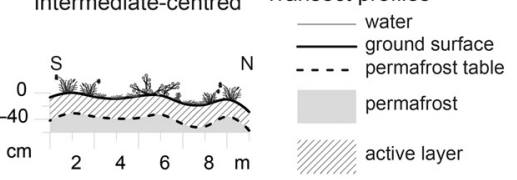

Roland Polygon

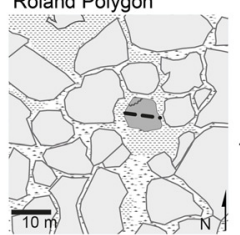

High-centred

Polygon fields

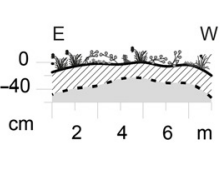

$\square$ ice-wedge polygon

$\square$ studied polygon

- - - position of transect

interpolygonal pond

interpolygonal mire

minn ice crack

Fig. 2 The four studied ice-wedge polygons in their settings. Polygon field close-ups on the left are digitized from Geoeye imagery. Ground surface height and permafrost table are shown along transects through each polygon.

Percent cover of taxa that occurred in at least two plots in each individual polygon was used for PCA of individual polygons using the same transformation and settings. The original data are available in the Supplementary file. Fitting of the environmental parameters relative surface height, active layer thickness, $\mathrm{pH}$ and TOC on the results of the PCA was conducted using default settings of the function "envfit" in vegan package. Environmental parameters that yielded a $P<0.05$ in the analysis were accepted as significant in the explanation of ordination patterns in the PCA.

We addressed our second goal of examining shrub expansion potential in polygon mires in the course of climatic warming in two ways: we first analysed the relation between climatically sensitive environmental parameters and shrub species cover in our data. We then discussed polygon mire development and degradation trends using the relevant literature.

We examined the relationship between (1) relative surface height and individual shrub taxa and (2) active layer depth and shrub taxa in univariate regression trees. We chose those two parameters as they are directly

affected by permafrost thaw. We used default settings of function "rpart" in the mvpart package in R (mvpart 2013), analysing percent cover of each shrub species against the above-mentioned environmental parameters for each polygon.

\section{Results}

\section{Polygon morphology and substrate characteristics}

We studied two low-centred polygons, one intermediatecentred polygon and one high-centred polygon. The polygon settings and morphology are illustrated in Fig. 3 and Supplementary Fig. S1. Herschel Polygon was a low-centred polygon surrounded by water-filled trenches. It measured $16 \mathrm{~m}$ from rim to rim and the maximum height difference between rim and low-lying centre was $25 \mathrm{~cm}$. Ptarmigan Polygon was a low-centred polygon surrounded by water-filled trenches with some standing water in the low-lying centre. It measured $12 \times 18 \mathrm{~m}$. The maximum height difference between rim and centre was $38 \mathrm{~cm}$. On one edge shared with an adjacent polygon of the same size and shape, the two polygon rims could not be distinguished and appeared as one. All other parts of the polygon rim were higher and bordered by water-filled and well-defined troughs. Komakuk Polygon was an intermediate-centred polygon. It was surrounded by

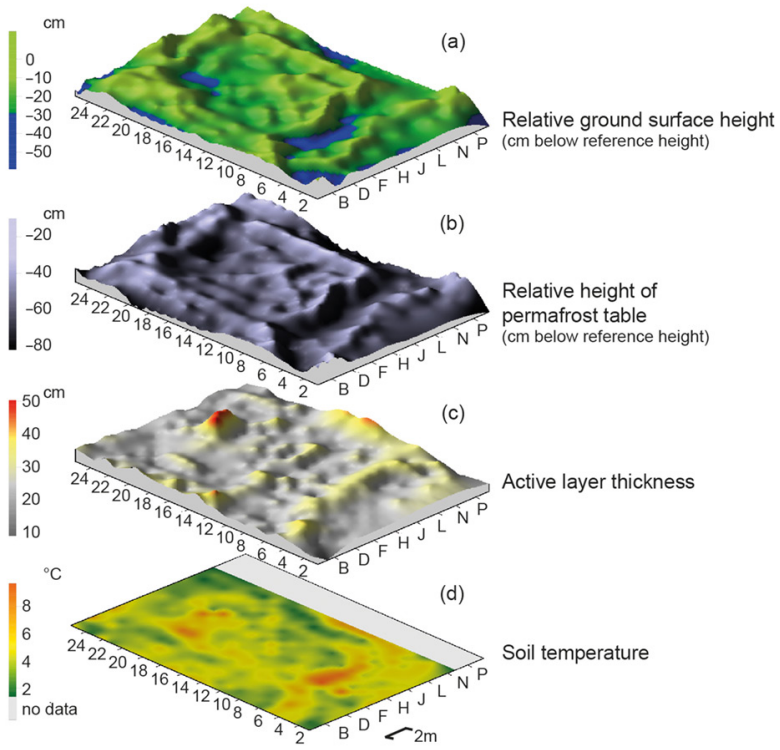

Fig. 3 Surface models of relative height of (a) ground surface, (b) permafrost table, (c) active layer depths and (d) soil temperatures in Ptarmigan Polygon. The blue colour in (b) illustrates an approximation of the position of the water table, which is seasonally and spatially variable because of the underlying permafrost. Plots of $1 \times 1 \mathrm{~m}$ named $\mathrm{A} 1$ through Q25 are labelled every $2 \mathrm{~m}$. 
narrow wet trenches, with ponds at the intersections of ice wedges. It measured $10 \mathrm{~m}$ from rim to rim. About half of the centre was low-lying, while the other half was not much below the rims. The maximum height difference was $29 \mathrm{~cm}$. Roland Polygon was a high-centred polygon measuring $10 \times 8 \mathrm{~m}$, which was surrounded by waterfilled trenches. The maximum height difference within the elevated parts of the polygon was $47 \mathrm{~cm}$. Another $28 \mathrm{~cm}$ height difference existed between the elevated polygon and the water table of the surrounding trenches. The surrounding water-filled trenches were up to $7 \mathrm{~m}$ wide. In these three polygons frost cracks were visible that were not bordered by ridges (Fig. 3).

A strong correlation between surface height and height of the underlying permafrost table was found for all four investigated ice-wedge polygons $(\rho=0.91, P<0.001$, Supplementary Table S1, Fig. 3). A lowered ground surface height was generally accompanied by a lowered permafrost table height (i.e., the relative height of the upper boundary surface of the permafrost); however, the decrease was not always of the same magnitude. Figure 3 illustrates relative surface height, permafrost table, active layer thickness and soil temperatures in Ptarmigan Polygon. The active layer was slightly shallower on ridges and thicker under standing water and in the central depression, but the relation was not strong (Fig. 3c). Ptarmigan Polygon had a deeper thawed spot in one of its ridges (Fig. 3c). Soil temperatures showed a similar pattern (Fig. 3d): they were lower on ridges and highest under standing water.

The measured substrate parameters $\mathrm{pH}$, electrical conductivity, TN and TOC were correlated with relative surface height (Supplementary Table S1). We attribute this relationship to the fact that the vegetation itself, especially litter of deciduous plants, influenced substrate build-up. The four polygons all had silty peat in the active layer. There was a general trend towards more finegrained material with increasing depth. The distribution of $\mathrm{pH}$ values was bimodal, with a peak around 4 for highand intermediate-centred polygons and another around 6 for low-centred polygons. Electrical conductivity in pore water ranged from $75.1 \mu \mathrm{S} / \mathrm{cm}$ in Komakuk Polygon to $681 \mu \mathrm{S} / \mathrm{cm}$ in Ptarmigan Polygon. Within polygons, electrical conductivity was higher in depressed situations and lower on elevated parts. TN contents ranged from 0.5 to $2.4 \%$ in surface samples. The lowest nitrogen contents were found in high-centred Roland Polygon. Medians and ranges of the measured environmental parameters in the investigated polygons are shown in Table 1.

\section{Relation of vascular plant species with microtopography and substrate}

Visual inspection in the field showed that vegetation distribution in the investigated polygon mires was linked to microrelief. Figure $4 \mathrm{a}$ illustrates the distribution of main plant functional types over surface profiles of the low-centred Ptarmigan Polygon and the high-centred Roland Polygon. Shrubs and graminoids were the most dominant groups. Shrubs were generally more abundant in the high- and intermediate-centred polygons, and graminoids were more abundant in the low-centred polygons.

We identified 36 species of vascular plants, of which 12 were shrub species (Betula glandulosa, Salix arctica, S. fuscescens, S. pulchra, S. reticulata, Dryas integrifolia, Rubus chamaemorus, Cassiope tetragona, Empetrum nigrum, Ledum decumbens, Vaccinium uliginosum and V. vitis-idaea) and

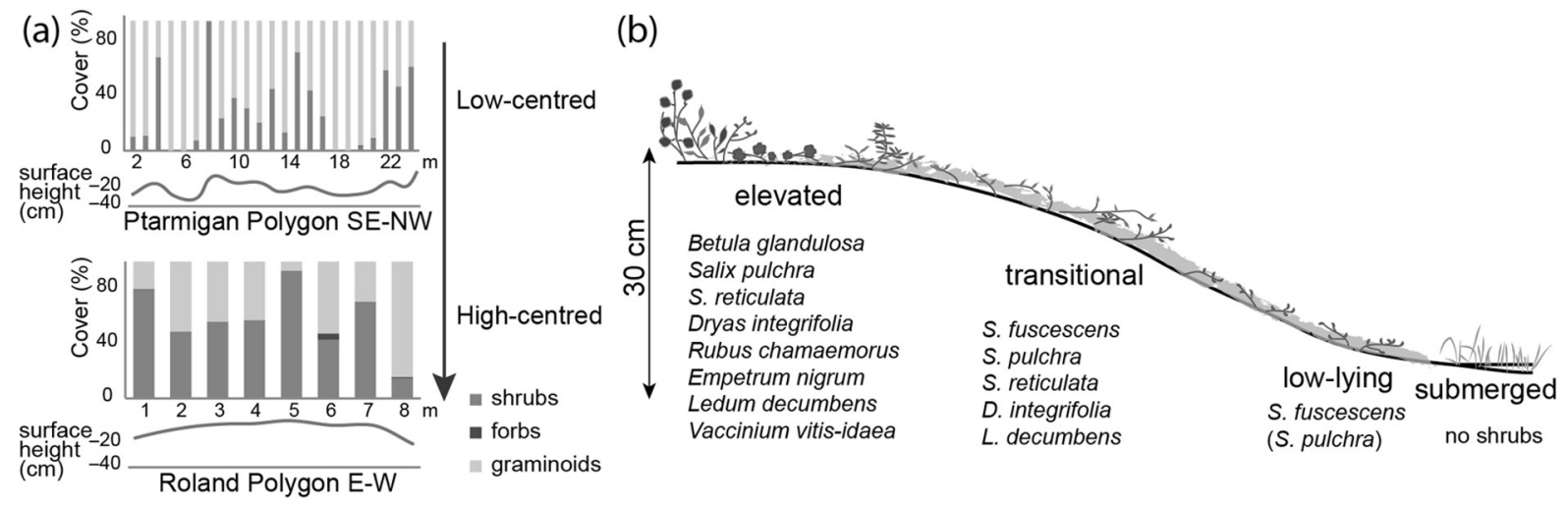

Fig. 4 Vegetation cover and distribution in the studied ice-wedge polygons. (a) The distribution of main plant functional types is linked to relative surface height. Shrub cover is increased on elevated surfaces. Graminoid cover is increased on low-lying surfaces in local depressions. The vegetation cover data are corrected to sum up to $100 \%$. Line graphs below stacked column graphs show the surface height relative to the highest point in each transect. (b) Schematic surface height ranges of shrub species in investigated ice-wedge polygon mires. Ranges are derived from univariate regression tree analysis. 
24 were herb species (Supplementary Table S2). Graminoids were the most dominant herb group, with sedge and cottongrass species having the highest cover. We identified four Carex species (C. aquatilis, C. chordorrhiza, C. rariflora and C. williamsii) and two Eriophorum species (E. angustifolium and E. vaginatum). Other graminoid species (Juncus biglumis, Luzula confusa, L. wahlenbergii, Hierochloë alpina, H. pauciflora, cf. Dupontia fisheri, Poa arctica) were found to have lower cover. Eleven of the 24 herb species were forbs (Pyrola grandiflora, Polygonum bistorta, P. viviparum, Pedicularis capitata, P. lanata, P. lapponica, P. oederi, P. sudetica, Saxifraga nelsoniana, Stellaria longipes and Tofieldia cf. pusilla). However, the total mean cover of forbs was only $0.8 \%$. We found more species of vascular plants in the low-centred Herschel and Ptarmigan polygons (22 and 21 species, respectively) than in the high- and intermediate-centred Roland and Komakuk polygons (16 and 9 species).

PCA of vascular plant species cover demonstrated that vegetation composition and cover was different in the four polygons (Fig. 5a). Sample scores of the two lowcentred polygons overlapped, as did those of the high- and intermediate-centred polygons. Vegetation composition and cover was thus different between polygon types (lowcentred vs. high- and intermediate-centred). The fitting of environmental variables to ordination results demonstrated that the vegetation-based PCA biplot is significantly correlated with microtopography, represented by relative surface height and active layer thickness, and with substrate, represented by $\mathrm{pH}$ and TOC (Fig. 5a).

In the PCA of vegetation cover data from the lowcentred Herschel and Ptarmigan polygons (Fig. 5b, c), the sample plots were clearly grouped according to their position on moist elevated rims or wet depressed centres. Environmental fitting analysis demonstrated that relative surface height correlated significantly with taxa composition and cover in both low-centred polygons. In Herschel Polygon, active layer thickness and $\mathrm{pH}$ also showed significant correlation with the ordination. In the PCAs of vegetation cover data from the intermediate-centred Komakuk Polygon (Fig. 5d) and the high-centred Roland Polygon (Fig. 5e), only plants of elevated mesic sites are found, and no clear vegetation groups were distinguished. In these two polygons, none of the measured environmental parameters significantly correlated with the taxa distribution in the PCA.

\section{Relation of shrub species with microtopography}

Shrub species were present in all investigated polygons. They were especially dominant in the high-centred Roland Polygon, the intermediate-centred Komakuk Polygon and on the ridges of the low-centred Ptarmigan and Herschel polygons (Supplementary Table S2, Fig. 4a). Shrub species restricted to elevated parts (in the highest $10 \mathrm{~cm}$ ) in the polygons include Betula glandulosa, Rubus chamaemorus, Empetrum nigrum, and Vaccinium vitis-idaea. Salix pulchra, S. reticulata, Dryas integrifolia, and Ledum decumbens were found both in transitional and elevated surface height ranges (in the highest $16 \mathrm{~cm}$ ). The relative surface height ranges we identified for each shrub species are shown in Fig. 4b. Salix fuscescens was associated with transitional to low-lying heights (below the highest $16 \mathrm{~cm}$ ). Active layer thickness (19-36 cm, Table 1) did not show clear trends in this analysis (Supplementary Table S2). We did not find $S$. fuscescens and $D$. integrifolia on active layers shallower than about $30 \mathrm{~cm}$. All other shrub species were also found on active layers less than $30 \mathrm{~cm}$ in thickness. Shrub species as a group were found on high and intermediate heights $(10-14[-20] \mathrm{cm})$ and on intermediate active layer depths. We found no shrubs in seasonally submerged situations.

\section{Discussion}

Permafrost thaw, thermokarst processes and degradation of ice wedges have been increasing during the last several decades over most of the Arctic tundra biome, and the trend is projected to continue and increase in intensity (AMAP 2011; Barros et al. 2014). Since polygon mire morphology is directly linked to permafrost conditions and the ground thermal regime, a continuation of this trend will likely trigger landscape-scale changes in lowland polygons.

We found that (1) our studied polygons on the Yukon Coastal Plain have undergone recent degradation, (2) the best predictor for vegetation and substrate is microtopography, and (3) shrub cover is greater in high-centred polygons. These findings suggest that a transition towards greater shrub cover could occur if recent permafrost thaw continues to increase as projected and these polygonal landscapes drain.

\section{Polygon morphology, microtopography and substrate characteristics}

The four studied polygons are in different ice wedge degradation states, all showing signs of recent degradation. Most of the ice wedges delineating the polygons are deeply thawed and the resulting troughs are water-filled (Figs. 2, 3). Ice wedges belonging to the same polygon are not necessarily all in the same state of degradation (Figs. 2, 3). This is consistent with findings from the Siberian Arctic, where ridge morphology of low-centred polygons has been found to be highly variable (de Klerk 

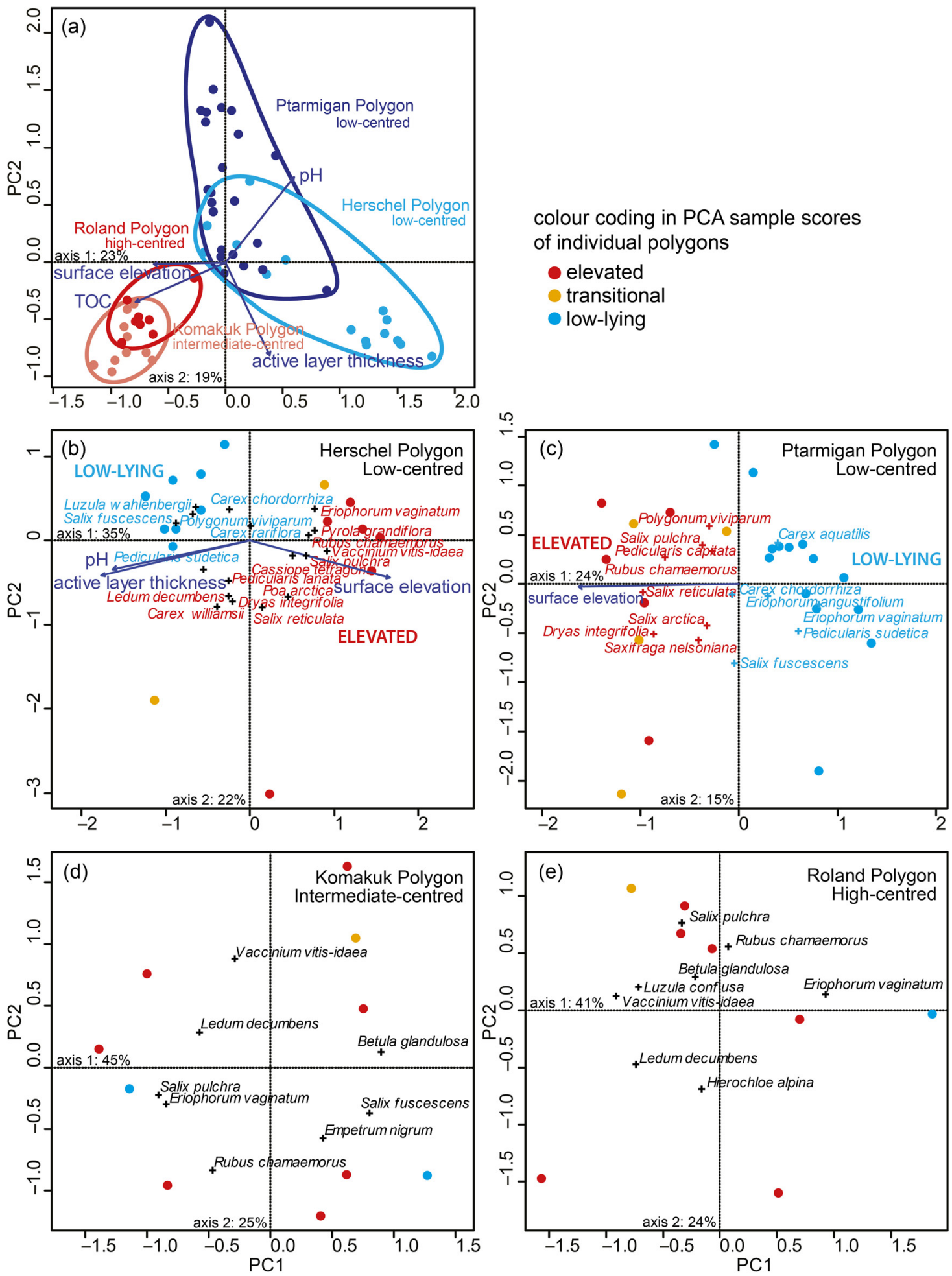

Fig. 5 (a) Vascular plant species composition and abundance differ between the investigated polygons. (b,c) Within low-centred polygons percent cover data of vascular plant species are clearly grouped into taxa related to either low-lying or elevated surfaces. (d) Intermediate-centred and (e) high-centred polygons are more similar. PCA plots show samples, species and environmental parameters. Species scores are indicated by a cross followed by the species name. The points indicate sample scores and the arrows indicate the correlation of environmental parameters with ordination results (only parameters with $P<0.05$ are shown). 
et al. 2011; Donner et al. 2012; Teltewskoi et al. 2016). Jorgenson et al. (2006) observed a series of stages of ice wedge degradation and stabilization in northern Alaska. According to their classification scheme, ice wedges belonging to Herschel, Ptarmigan and Komakuk polygons show intermediate (obvious settlement and shallow standing water) to advanced (deep, water-filled pits) degradation. The ice wedges surrounding Roland Polygon are in a state of advanced degradation to initial stabilization (robust aquatic sedges in shallow water). The presence of higherorder ice wedges within the polygons (Fig. 2) also indicates degrading primary ice wedges. Mackay (1993, 2000) argues that secondary or tertiary ice wedges develop in order to relieve thermal stresses when primary ice wedges become deeply thawed and crack less frequently. Our results strongly suggest that ice wedge degradation is ongoing on the Yukon Coastal Plain and already advanced in some cases.

Continuing ice wedge degradation leads to a relief inversion in low-centred polygons (Jorgenson et al. 2006; French 2007), which ultimately drain the wet low-lying polygon centres through subsurface flow paths (Fortier et al. 2007; Fig. 3a, b). Individual ridges around a polygon may develop differently, but generally the formerly wet to submerged centres will become drier during ice wedge degradation (de Klerk et al. 2011; Donner et al. 2012; Teltewskoi et al. 2016). Deeper thaw in ridges of lowcentred polygons has been linked to flow paths of water created by thermal erosion processes (Minke et al. 2009; de Klerk et al. 2011; de Klerk et al. 2014). In our polygons, relative surface height and subsurface water pathways are strongly linked to the relative height of the permafrost table (Fig. 3, Supplementary Table S1).

The substrate characteristics of our surface samples are generally comparable to those of lowland polygonal terrain on the coastal plain of Alaska and in northeast Siberia (Lipson et al. 2010; Donner et al. 2012; Zibulski et al. 2013). We found very low $\mathrm{pH}$ values in high-centred polygons and on the elevated ridges of low-centred polygons, and slightly acidic to neutral $\mathrm{pH}$ values in low-lying areas (Table 1, Supplementary Table S3). Lipson et al. (2010) and Donner et al. (2012) found a similar negative correlation between $\mathrm{pH}$ and relative surface height. Nutrient contents, approximated by electrical conductivity and nitrogen contents, also correlate negatively with relative surface height (Supplementary Table S1). High-centred polygons contain more elevated ground and consequently lower nutrient contents than low-centred polygons (Fig. 6). A change in polygon morphology over much of the Yukon Coastal Plain could therefore lead to changes in soil geochemistry, with a lowering of the $\mathrm{pH}$ and a decrease in the amount of available nutrients.

\section{Relation of vascular plant species with microtopography and substrate}

In the polygons we studied, the best predictor for vegetation and substrate was microtopography (Figs. 4, 6). The highest surfaces provided mesic, acidic, nutrient-poor habitats. In low-centred polygons there was a transitional zone of a few centimetres towards wet, circumneutral and less nutrient-poor habitats. Peaty substrates develop from plant litter. They therefore not only provide the basis for vegetation growth but are also highly influenced by vegetation composition. Acidic, nutrient-poor substrates on elevated surfaces are unsuitable for many plant species. In our study, elevated areas in high-centred polygons were dominated by Betula glandulosa, Eriophorum vaginatum tussocks and ericaceous dwarf shrubs, while elevated areas in low-centred polygons were dominated by Salix sp., Rubus chamaemorus, ericaceous dwarf shrubs and a variety of graminoids and forbs (Fig. 6). Low-lying areas were dominated by Carex sp., Eriophorum sp. and to some extent Salix fuscescens (Fig. 6). The highest shrub cover occurred in the highest $10-15 \mathrm{~cm}$ (Supplementary Table S3). Studies of Siberian and Alaskan ice-wedge polygons have found a similar relationship between surface height and plant species composition (Bliss 1956; de Klerk et al. 2009; Zibulski et al. 2013; de Klerk et al. 2014).

We found fewer vascular plant species in high-centred polygons compared with low-centred polygons (Supplementary Table S2). Forbs and graminoids found on elevated areas, such as Carex williamsii, Eriophorum vaginatum, Poa arctica, Pedicularis sudetica, Pyrola grandiflora, Polygonum viviparum, Saxifraga nelsoniana and some less abundant species, could face increased competition for light, nutrients and rooting space if their current habitat is subject to shrub increase. Our findings suggest that a change from a low-centred polygon landscape to a highcentred one would have a significant impact on plant species abundance, with a potential overall increase in shrubs versus graminoids in Low Arctic tundra.

\section{Regional implications}

During recent decades climatic warming (Burn \& Zhang 2009), greening of the landscape (Fraser et al. 2012) and local shrub increase (Myers-Smith, Hik et al. 2011) have been observed in the study area. We found that height differences of a few centimetres are sufficient to alter vegetation and substrate conditions in degrading polygon mires on the Yukon Coastal Plain and Herschel Island 


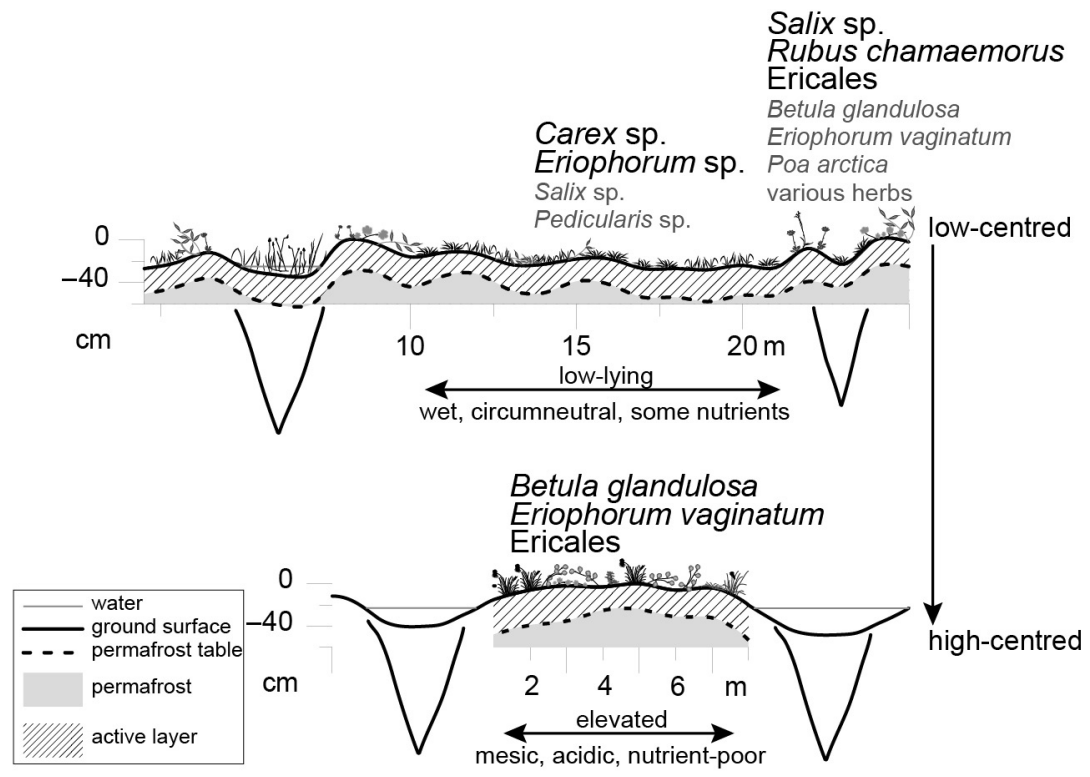

Fig. 6 Schematic diagram showing three main microhabitats of ice-wedge polygon mires (low-centred low-lying, low-centred elevated, high-centred elevated). Dominant vascular plant taxa are indicated for each microhabitat. Permafrost table and ground surface heights are taken from graphically interpolated actual measurements (Supplementary Table S4) every metre. Position, size and depth of ice wedges and ground surface height in the troughs of Roland Polygon are schematic illustrations.

(Figs. 4b, 6, Supplementary Table S3). We suggest that continued climatic warming, leading to permafrost thaw and ground subsidence preferentially on top of ice wedges, is likely to enhance microrelief inversion in polygon mires. This, in turn, could promote an increase of acidic shrub tundra and a corresponding decrease of circumneutral graminoid tundra in lowland polygonal terrain (Fig. 6). While plant species shifts that are strictly climatically driven are theoretically reversible, polygon degradation and subsequent vegetation change are irreversible on decadal to centennial timescales.

The impact of environmental change on vegetation in ice-wedge polygons could partly be compensated by regional landscape heterogeneity, which provides a buffer for ecosystem response to global warming (Post et al. 2009). The availability of suitable microhabitats limits or enhances shrub expansion in tundra landscapes (Lloyd et al. 2003). Modern vegetation patterns suggest that the polygonal lowlands of the Yukon Coastal Plain could experience shrub increase on newly elevated polygon centres and a decrease in shrub cover in widened and submerged polygon troughs. Species typically found in low-lying polygon centres could, however, potentially prevail around the narrow edges between elevated centres and deeply submerged troughs. These potential vegetation pathways for polygonal wetlands on the Yukon Coastal Plain relate to changes in plant species cover and to changing dominance. Plant species diversity may not be directly affected by a conversion of low-centred polygons into high-centred polygons. As long as polygonal structures are preserved, different microhabitats will likely exist within a close range of each other. An increase of shrubdominated tundra at the expense of graminoid dominated tundra could, however, considerably alter land surface properties. Snow retention potential could for instance be increased through the growth of shrubs, thereby altering albedo and ground thermal regime (Myers-Smith, Forbes et al. 2011; Myers-Smith et al. 2015). Melting of ice wedges could promote the interconnection of polygon troughs and promote water flow across the landscape (Liljedahl et al. 2012; Godin et al. 2014). All of these changes could drastically alter greenhouse gas flux from the land surface (Kutzbach et al. 2004; Kutzbach et al. 2007; Wille et al. 2008; Sachs et al. 2010; von Fischer et al. 2010). In other areas of the Arctic, ponding and vegetation changes have been shown to trigger substantial changes in the surface energy balance (Langer et al. 2011a, b; Muster et al. 2012).

We therefore suggest three main implications of a possible increase in high-centred polygons in the region: (1) shrub increase and acidification on elevated polygon centres; (2) snow redistribution on the landscape; and (3) increased connectivity of surface water on top of ice wedges. 


\section{Conclusions}

Our study demonstrates that vegetation composition in ice-wedge polygon mires on the Yukon Coastal Plain and Herschel Island is strongly related to microtopography, which is controlled by geomorphological processes such as ice wedge degradation. Ericaceous and other dwarf shrubs and low shrubs (Rubus chamaemorus, Betula glandulosa, Salix spp.) are generally more abundant on elevated areas in the polygons. Graminoids, especially sedges (Carex sp.), are more abundant in low-lying settings. We suggest that a regime shift towards shrubby high-centred polygons is possible if recent permafrost thaw continues to increase as projected. Plant species shifts that are strictly climatically driven are theoretically reversible, but widespread polygon degradation leads to changes in microtopography that are irreversible on decadal to centennial timescales. However, increased ponding between polygons induced by thawing permafrost may limit the areal expansion potential of shrubs and provide new microhabitats for aquatic species. In the course of the next years and decades, the regional water balance will likely determine future vegetation trajectories for tundra wetlands. We therefore stress the importance of including geomorphological change in addition to climatic change parameters such as rising summer temperatures in vegetation change predictions.

\section{Acknowledgements}

We thank the Yukon Territorial Government, the Yukon Parks (Herschel Island Qiqiktaruk Territorial Park) and Parks Canada Office (Ivvavik National Park) for their administrative support. We received great logistical and administrative help from the Aurora Research Institute in Inuvik, NT, Canada. We are grateful for the help Louise Beveridge, Tyne Brückner, Anna Konopczak, Ute Kuschel, Izabela Milczarek, Boris Radosavljevic, George Tanski and Stefanie Weege provided in the field and in the laboratory. Annika Trimble provided plant identification training. We thank the rangers of Ivvavik Territorial Park for their support in everything from logistics to opinions derived from their long-term observances in the field. We are particularly grateful to two reviewers, whose comments greatly improved the clarity and focus of the paper. This work was partly funded by the Helmholtz Association (grant no.VH-NG-801) and the International Bureau of the German Federal Ministry of Education and Research (BMBF grant no. CAN 09/001, 01DM12002). JW was financed and supported by the Helmholtz Graduate School for Polar and Marine Research.

\section{References}

AMAP 2011. Snow, Water, Ice end Permafrost in the Arctic (SWIPA): climate change and the cryosphere. Oslo: Arctic Monitoring and Assessment Programme.

Barros V.R., Field C.B., Dokken D.J., Mastrandrea M.D., Mach K.J., Bilir T.E., Chatterjee M., Ebi K.L., Estrada Y.O., Genova R.C., Girma B., Kissel E.S., Levy A.N., MacCracken S., Mastrandrea P.R. \& White L.L. (eds.). 2014. Climate change 2014 . impacts, adaptation, and vulnerability. Part B: regional aspects. Contribution of Working Group II to the fifth assessment report of the Intergovernmental Panel on Climate Change. Cambridge: Cambridge University Press.

Bliss L.C. 1956. A comparison of plant development in microenvironments of Arctic and alpine tundras. Ecological Monographs 26, 303-337.

Braun-Blanquet J. 1964. Pflanzensoziologie: Grundzüge der Vegetationskunde. (Plant sociology - the study of plant communities.) Vienna: Springer Verlag.

Brown J., Ferrians O.J., Heginbottom J. \& Melnikov E. 1997. Circum-Arctic map of permafrost and ground-ice conditions. Reston, VA: US Geological Survey.

Burn C.R. 1997. Cryostratigraphy, paleogeography, and climate change during the early Holocene warm interval, western Arctic coast, Canada. Canadian Journal of Earth Sciences 34, 912-925.

Burn C.R. \& Zhang Y. 2009. Permafrost and climate change at Herschel Island (Qikiqtaruq), Yukon Territory, Canada. Journal of Geophysical Research - Earth Surface 114, F02001, doi: http://dx.doi.org/10.1029/2008JF001087

CAVM Team 2003. Circumpolar Arctic vegetation map. Scale 1:7,500,000. Conservation of Arctic Flora and Fauna (CAFF) Map no. 1. Anchorage: US Fish and Wildlife Service.

de Klerk P., Donner N., Joosten H., Karpov N.S., Minke M., Seifert N. \& Theuerkauf M. 2009. Vegetation patterns, recent pollen deposition and distribution of non-pollen palynomorphs in a polygon mire near Chokurdakh (NE Yakutia, NE Siberia). Boreas 38, 39-58.

de Klerk P., Donner N., Karpov N.S., Minke M. \& Joosten H. 2011. Short-term dynamics of a low-centred ice-wedge polygon near Chokurdakh (NE Yakutia, NE Siberia) and climate change during the last ca 1250 years. Quaternary Science Reviews 30, 3013-3031.

de Klerk P., Teltewskoi A., Theuerkauf M. \& Joosten H. 2014. Vegetation patterns, pollen deposition and distribution of non-pollen palynomorphs in an ice-wedge polygon near Kytalyk (NE Siberia), with some remarks on Arctic pollen morphology. Polar Biology 37, 1393-1412.

Donner N., Minke M., Klerk P.D., Sofronov R. \& Joosten H. 2012. Patterns in polygon mires in north-eastern Yakutia, Siberia: the role of vegetation and water. The Finnish Environment 38, 19-30.

Dyke A.S. \& Prest V.K. 1987. Late Wisconsinan and Holocene history of the Laurentide ice sheet. Geographie physique et Quaternaire 41, 237-263.

Ellis C., Rochefort L., Gauthier G. \& Pienitz R. 2008. Paleoecological evidence for transitions between contrasting 
landforms in a polygon-patterned High Arctic wetland. Arctic, Antarctic, and Alpine Research 40, 624-637.

Fortier D., Allard M. \& Shur Y. 2007. Observation of rapid drainage system development by thermal erosion of ice wedges on Bylot Island, Canadian Arctic Archipelago. Permafrost and Periglacial Processes 18, 229-243.

Fraser R., Olthof I., Carrière M., Deschamps A. \& Pouliot D. 2012. A method for trend-based change analysis in Arctic tundra using the 25-year Landsat archive. Polar Record 48, 83-93.

French H.M. 2007. The periglacial environment. 3rd edn. Chichester: John Wiley \& Sons.

Fritz M., Wetterich S., Schirrmeister L., Meyer H., Lantuit H., Preusser F. \& Pollard W.H. 2012. Eastern Beringia and beyond: late Wisconsinan and Holocene landscape dynamics along the Yukon Coastal Plain, Canada. Palaeogeography, Palaeoclimatology, Palaeoecology 319-320, 28-45.

Fritz M., Wolter J., Rudaya N., Palagushkina O., Nazarova L., Obu J., Rethemeyer J., Lantuit H. \& Wetterich S. 2016. Holocene ice-wedge polygon development in northern Yukon permafrost peatlands, Canada. Quaternary Science Reviews, doi: http://dx.doi.org/10.1016/j.quascirev.2016.02.008

Frost G.V. \& Epstein H.E. 2014. Tall shrub and tree expansion in Siberian tundra ecotones since the 1960s. Global Change Biology 20, 1264-1277.

Frost G.V., Epstein H.E. \& Walker D.A. 2014. Regional and landscape-scale variability of Landsat-observed vegetation dynamics in northwest Siberian tundra. Environmental Research Letters 9, article no. 025004. doi: http://dx.doi.org/ 10.1088/1748-9326/9/2/025004

Godin E., Fortier D. \& Coulombe S. 2014. Effects of thermoerosion gullying on hydrologic flow networks, discharge and soil loss. Environmental Research Letters 9, article no. 105010, doi: http://dx.doi.org/10.1088/1748-9326/9/10/105010

Hagenstein R., Sims M., Mann G. \& Ricketts T.H. 1999. Arctic coastal tundra. In T.H. Ricketts (ed.): Terrestrial ecoregions of North America: a conservation assessment. Pp. 398-400. Washington, DC: Island Press.

Haugen R.K. \& Brown J. 1980. Coastal-inland distributions of summer air temperature and precipitation in northern Alaska. Arctic and Alpine Research 12, 403-412.

Jorgenson M.T., Shur Y.L. \& Pullman E.R. 2006. Abrupt increase in permafrost degradation in Arctic Alaska. Geophysical Research Letters 33, L02503, doi: http://dx.doi. org/10.1029/2005GL024960

Kutzbach L., Wagner D. \& Pfeiffer E.-M. 2004. Effect of microrelief and vegetation on methane emission from wet polygonal tundra, Lena Delta, northern Siberia. Biogeochemistry 69, 341-362.

Kutzbach L., Wille C. \& Pfeiffer E.-M. 2007. The exchange of carbon dioxide between wet Arctic tundra and the atmosphere at the Lena River Delta, northern Siberia. Biogeosciences Discussions 4, 1953-2005.

Langer M., Westermann S., Muster S., Piel K. \& Boike J. 2011 a. The surface energy balance of a polygonal tundra site in northern Siberia. Part 1: spring to fall. The Cryosphere 5, 151-171.

Langer M., Westermann S., Muster S., Piel K. \& Boike J. 2011 b. The surface energy balance of a polygonal tundra site in northern Siberia. Part 2: winter. The Cryosphere 5, 509-524.

Lantz T., Gergel S. \& Kokelj S. 2010. Spatial heterogeneity in the shrub tundra ecotone in the Mackenzie Delta region, Northwest Territories: implications for Arctic environmental change. Ecosystems 13, 194-204.

Liljedahl A.K., Hinzman L.D. \& Schulla J. 2012. Ice-wedge polygon type controls low-gradient watershed-scale hydrology. In K.M. Hinkel (ed.): Tenth International Conference on Permafrost. International contributions. Vol. 1. Pp. 231-236. Salekhard, Russia: The Northern Publisher.

Lipson D.A., Jha M., Raab T.K. \& Oechel W.C. 2010. Reduction of iron (III) and humic substances plays a major role in anaerobic respiration in an Arctic peat soil. Journal of Geophysical Research-Biogeosciences 115, G00I06, doi: http:// dx.doi.org/10.1029/2009JG001147

Lloyd A.H., Yoshikawa K., Fastie C.L., Hinzman L. \& Fraver M. 2003. Effects of permafrost degradation on woody vegetation at Arctic treeline on the Seward Peninsula, Alaska. Permafrost and Periglacial Processes 14, 93-101.

Mackay J.R. 1959. Glacier ice-thrust features of the Yukon coast. Geographical Bulletin 13, 5-21.

Mackay J.R. 1993. Air temperature, snow cover, creep of frozen ground, and the time of ice-wedge cracking, western Arctic coast. Canadian Journal of Earth Sciences 30, 1720-1729.

Mackay J.R. 2000. Thermally induced movements in icewedge polygons, western Arctic coast: a long-term study. Geographie Physique et Quaternaire 54, 41-68.

Minke M., Donner N., Karpov N., de Klerk P. \& Joosten H. 2009. Patterns in vegetation composition, surface height and thaw depth in polygon mires in the Yakutian Arctic (NE Siberia): a microtopographical characterisation of the active layer. Permafrost and Periglacial Processes 20, 357-368.

Muster S., Langer M., Heim B., Westermann S. \& Boike J. 2012. Subpixel heterogeneity of ice-wedge polygonal tundra: a multi-scale analysis of land cover and evapotranspiration in the Lena River Delta, Siberia. Tellus B 64, doi: http:// dx.doi.org/10.3402/tellusb.v64i0.17301

mvpart 2013. rpart. R package version 1.6-1.

Myers-Smith I., Elmendorf S., Beck P., Wilmking M., Hallinger M., Blok D., Tape K., Rayback S., Macias-Fauria M., Speed J., Boulanger-Lapointe N., Rixen C., Lévesque E., Schmidt N., Baittinger C., Trant A., Hermanutz L., Collier L.S., Dawes M., Lantz T., Weijers S., Jørgensen R.H., Buchwal A., Buras A., Naito A., Ravolainen V., Schaepman-Strub G., Wheeler J., Wipf S., Guay K., Hik D. \& Vellend M. 2015. Climate sensitivity of shrub growth across the tundra biome. Nature Climate Change 5, 887-891.

Myers-Smith I., Hik D., Kennedy C., Cooley D., Johnstone J., Kenney A. \& Krebs C. 2011. Expansion of canopy-forming willows over the twentieth century on Herschel Island, Yukon Territory, Canada. Ambio 40, 610-623. 
Myers-Smith I.H., Forbes B.C., Wilmking M., Hallinger M., Lantz T., Blok D., Tape K.D., Macias-Fauria M., Sass-Klaassen U., Lévesque E., Boudreau S., Ropars P., Hermanutz L., Trant A., Collier L.S., Weijers S., Rozema J., Rayback S.A., Schmidt N.M., Schaepman-Strub G., Wipf S., Rixen C., Ménard C.B., Venn S., Goetz S., Andreu-Hayles L., Elmendorf S., Ravolainen V., Welker J., Grogan P., Epstein H.E. \& Hik D.S. 2011. Shrub expansion in tundra ecosystems: dynamics, impacts and research priorities. Environmental Research Letters 6, article no. 045509, doi: http://dx.doi.org/10. 1088/1748-9326/6/4/045509

Naito A.T. \& Cairns D.M. 2011. Relationships between Arctic shrub dynamics and topographically derived hydrologic characteristics. Environmental Research Letters 6, article no. 045506, doi: http://dx.doi.org/10.1088/1748-9326/6/4/045506

Necsoiu M., Dinwiddie C.L., Walter G.R., Larsen A. \& Stothoff S.A. 2013. Multi-temporal image analysis of historical aerial photographs and recent satellite imagery reveals evolution of water body surface area and polygonal terrain morphology in Kobuk Valley National Park, Alaska. Environmental Research Letters 8, 25007-25022.

Oksanen J.F., Blanchet G., Kindt R., Legendre P., Minchin P.R., O'Hara R.B., Simpson G.L., Solymos P., Stevens M.H.H. \& Wagner H. 2013. Vegan: Community Ecology Package. R package version 2.0-9. Accessed on the internet at http://CRAN.Rproject.org $/$ package $=$ vegan

Post E., Forchhammer M.C., Bret-Harte M.S., Callaghan T.V., Christensen T.R., Elberling B., Fox A.D., Gilg O., Hik D.S., Høye T.T., Ims R.A., Jeppesen E., Klein D.R., Madsen J., McGuire A.D., Rysgaard S., Schindler D.E., Stirling I., Tamstorf M.P., Tyler N.J.C., van der Wal R., Welker J., Wookey P.A., Schmidt N.M. \& Aastrup P. 2009. Ecological dynamics across the Arctic associated with recent climate change. Science 325, 1355-1358.

Rampton V.N. 1982. Quaternary geology of the Yukon Coastal Plain. Geological Survey of Canada Bulletin 317. Ottawa: Geological Survey of Canada.

Rao C.R. 1995. A review of canonical coordinates and an alternative to correspondence analysis using Hellinger distance. Qüestiió 19, 23-63.

R Core Team 2013. A language and environment for statistical computing. Vienna: R Foundation for Statistical Computing.

Ropars P. \& Boudreau S. 2012. Shrub expansion at the forest-tundra ecotone: spatial heterogeneity linked to local topography. Environmental Research Letters 7, article no. 015501, doi: http://dx.doi.org/10.1088/1748-9326/7/1/015501

Sachs T., Giebels M., Boike J. \& Kutzbach L. 2010. Environmental controls on $\mathrm{CH} 4$ emission from polygonal tundra on the microsite scale in the Lena river delta, Siberia. Global Change Biology 16, 3096-3110.
Shaver G.R. \& Chapin F.S. III. 1980. Response to fertilization by various plant growth forms in an Alaskan tundra: nutrient accumulation and growth. Ecology 61, 662-675.

Tape K.E.N., Sturm M. \& Racine C. 2006. The evidence for shrub expansion in northern Alaska and the pan-Arctic. Global Change Biology 12, 686-702.

Teltewskoi A., Beermann F., Beil I., Bobrov A., Klerk P.D., Lorenz S., Lüder A., Michaelis D. \& Joosten H. 2016. 4000 years of changing wetness in a permafrost polygon peatland (Kytalyk, NE Siberia): a comparative high-resolution multiproxy study. Permafrost and Periglacial Processes 27, 76-95.

ter Braak C.J.F. 1983. Principal components biplots and alpha and beta diversity. Ecology 64, 454-462.

Von Fischer J.C., Rhew R.C., Ames G.M., Fosdick B.K. $\delta$ von Fischer P.E. 2010. Vegetation height and other controls of spatial variability in methane emissions from the Arctic coastal tundra at Barrow, Alaska. Journal of Geophysical Research—Biogeosciences 115, article no. G00I03, doi: http:// dx.doi.org/10.1029/2009JG001283

Walker D.A. 2000. Hierarchical subdivision of Arctic tundra based on vegetation response to climate, parent material and topography. Global Change Biology 6, 19-34.

Walker D.A., Jia G.J., Epstein H.E., Raynolds M.K., Chapin F.S., III, Copass C., Hinzman L.D., Knudson J.A., Maier H.A., Michaelson G.J., Nelson F., Ping C.L., Romanovsky V.E. \& Shiklomanov N. 2003. Vegetation-soil-thaw-depth relationships along a Low-Arctic bioclimate gradient, Alaska: synthesis of information from the ATLAS studies. Permafrost and Periglacial Processes 14, 103-123.

Walker D.A., Raynolds M.K., Daniëls F.J., Einarsson E., Elvebakk A., Gould W.A., Katenin A.E., Kholod S.S., Markon C.J. \& Melnikov E.S. 2005. The circumpolar Arctic vegetation map. Journal of Vegetation Science 16, 267-282.

Washburn A.L. 1979. Geocryology: a survey of periglacial processes and environments. London: Blackburn Press.

Westhoff V. \& Van Der Maarel E. 1978. The Braun-Blanquet approach. In R. Whittaker (ed.): Classification of plant communities. Pp. 287-399. The Hague: Dr W. Junk Publishers.

Wille C., Kutzbach L., Sachs T., Wagner D. \& Pfeiffer E.-M. 2008. Methane emission from Siberian Arctic polygonal tundra: eddy covariance measurements and modeling. Global Change Biology 14, 1395-1408.

Zibulski R., Herzschuh U., Pestryakova L.A., Wolter J., Müller S., Schilling N., Wetterich S., Schirrmeister L. \& Tian F. 2013. River flooding as a driver of polygon dynamics: modern vegetation data and a millennial peat record from the Anabar River lowlands (Arctic Siberia). Biogeosciences 10, 5703-5728. 